\title{
From Islamicizing the Sciences to Strategizing for Muslims' Scientific Breakthrough
}

\author{
RAFIU IBRAHIM ADEBAYO 1
}

\begin{abstract}
At inception, science and religion were seen as poles apart and so science was vehemently kicked against by religious leaders. Islam later came to bridge the gap between religion and science only to be later hijacked by the Western world and so science was rewritten from a purely materialist point of view; hence, experts in modern science became over-confident and arrogant to have relegated religion to the lowest ebb and looked down upon any knowledge which could not be scientifically proved. However attempts are being made to reconcile religion and science by Muslim reformers. These attempts are not without their shortcomings, hence the need for Islamization of the sciences for them to conform to the Islamic principle of unity of knowledge. However, the present researcher feels that there should be a step forward from the contemporary approaches to Islamicizing the sciences in form of colouring the Western scientific discoveries Islam, to making their own scientific breakthroughs, the type which immortalized Muslim scientists of the Islam's golden ages. Without this, Muslims will continue to be mere consumers of the Western products. The strategy for the Ummah to achieve this is suggested in this paper.
\end{abstract}

Keywords: Islamicizing, Islamisation, Islamic thought, religion and science

Ever before the advent of Islam and the eventual active involvement of Muslims in scientific discoveries, there seemed to have been an irreconcilable conflict between religion and science. Theologians and scientists were always at logger head on issues that culminated in many losing their faith for the fact that religious teachings seemed dogmatic. The difference between the Church and the scientists degenerated to the extent that the Church used its power to humiliate and even assassinate some scientists. This episode is aptly captured by Bucaille (1993: 125) when he writes:

\begin{abstract}
The relationship between religions and science has not always been the same in any one place or time. It is a fact there is no writing belonging to a monotheistic religion that condemns science. In practice however, it must be admitted that scientists have had great difficulties with the religious authorities of certain creeds. For many centuries, in the Christian world, scientific development was opposed by the authorities in question, on their own initiative and without reference to the authentic Scriptures. We already know the measures taken against those who sought to enlarge science, measures which often made scientists go into exile to avoid being burnt at the stake, unless they recanted, changed their attitude and begged for pardon. The case of Galileo is always cited in this context: he was tried for having resumed the discoveries made by Copernicus on the rotation of the Earth. Galileo was condemned as the result of a mistaken interpretation of the Bible, since not a single Scripture could reasonably be brought against him.
\end{abstract}

\footnotetext{
${ }^{1}$ Rafiu Ibrahim Adebayo, Ph.D., Lecturer, Department of Religions, University of Ilorin, P.M.B. 1515 ILORIN, Nigeria, email: adrafhope@yahoo.com, rafiu@unilorin.edu.ng.
} 
From the above excerpt, it could be inferred that the assumed conflict between science and theology is not because religion is antagonistic of science, but because the theologians then were not accommodating enough to have allowed the scientists to exercise their talents and discoveries for the promotion of human race. The Christian ecclesiastical authorities for instance prohibited the dissection of the human body because of the sanctity of the body. Also, the discovery of curative drugs for different ailments by scientists was considered outrageous and an attempt to avert disease which was a punishment of the Almighty for human sins and which could only be averted by prayer and intercession by saints (Adamu 2002). In addition, the Church was not ready to listen to the scientists especially where any scientific discovery did not tally with that of the Church. Corpernicus for instance discovered that the earth was not the centre of the universe, not static, but moving around the sun. This was contrary to the submission of the Church that the earth was the centre of the universe, which was static and the sun and the stars moved round it. For these discrepancies, Corpernicus' book, entitled The Revolutions which published this discovery was banned from circulation, while Galileo who shared the same opinion with Corpernicus on the earth's movement was sentenced to death. Such scientists as Wycliffe, Bruno, Bacon, Galileo and many others also suffered persecution by the theologians who were not ready to listen to any discovery except the church dogmas. Capturing the suffering and inhuman treatment of scientists in the hand of the Church, Hoodbhoy (1991) has this to say:

\begin{abstract}
But historically, it is the Christian orthodoxy which fought the longest and most bitter battle against science. For a thousand years before the Renaissance, the Christian Church had ruled Europe with an iron hand. Intolerance, prejudice, suspicion and superstition had made scholarly learning an impossibility. Suspicious of every attempt at independent thinking, the Church violently suppressed all teaching that was not in direct conformity with its teachings. Religious tribunals sentenced tens of thousands of suspected witches and heretics to death by torture. Convicts were tied between horses and torn apart, disemboweled, hung or burnt at the stake. Even the dead were not forgiven. The famous Archbishop Ussher had concluded from his study of the Bible that the world began at 9 a.m., Sunday 23 October 4004 B.C. - this despite the fact that a long dead scientist, Wycliffe, had provided evidence based on fossils and geology that the earth was at least some hundred thousand years old. Unable to tolerate this insolence, the Church ordered that Wycliffe's bones be dug up, broken in pieces, and thrown into the sea so that the germs of dissent and doubt might no longer contaminate the earth.
\end{abstract}

The resultant effect of the maltreatment of the scientists by the Church on religion was not palatable at all, as those who managed to escape amongst them decided not only to isolate themselves from religion, but also to mount strong opposition on it, kicking vehemently against it in order to establish themselves. Their hostility against religion was manifested in their denial of heavenly truths and the existence of God; their separation of science from religion; their elevation of science over religion and their claim than no divine guidance is needed for man to survive in this world (Adamu 2002). The above was the interaction between theologians and scientists in the Christendom before the advent of Islam. Conversely however, the Muslims after their contacts with foreign cultures and civilizations accommodated these civilizations and cultures and so absorbed them into the mainstream of their civilization. They later developed sciences to their religious tastes and made their contributions to them. Between the period of 750-1100 CE, Muslim scientists shook the world with their numerous scientific discoveries. Many Muslims were able to make names unequaled in the West. Such names as cited by AlFaruq (2003) included Jabir ibn Qurra, al-Kindi, al-Khawarizmi al-Farghani, al-Razi, Thabit ibn Qurran, al-Battani, Hunain ibn Ishaq, al-Farabi, Ibrahim ibn Sinan, al-Mas'udi, al-Tabari, AbdulWafa', Ali ibn Abbas, Abu'l -Qasim, ibn al-Jazzar, al-Biruni, Ibn Sina. Ibn Yunus. Al-Karbi, Ibn alHaitham, Ali ibn 'Isa al-Ghazzali, al-Zarqali, 'Umar Khayyam, and a host of others. Afterwards, they became renowned in all spheres of scientific endeavours. Also, great universities sprang up 
in such Muslim territories as Baghdad, Kufa, Basra, Cairo and Cordova. These institutions attracted students from all parts of the world particularly Europe. Many works in Arabic were also translated into Latin, an effort which according to Haque (2010) marked the beginning of European research.

\section{Muslims and Scientific Development}

By the time the Arabs engaged themselves in serious literary production, the Greek, the Roman, the Alexandrian, the Syrian, the Sassanian or the Persian, the Hindu, the Buddhist and the Chinese science and civilization had reached their zenith. By 520 C.E. Bodhiharma, the Ch'an or contemplative school of Buddhism was established, while Buddhists like Paramartha and Jinagupta settled among the Turks and in China, translating many writings from Sanskrit into Chinese and Turkish (Husaini 1986). The final closure of the famous Academy of Athens in 529 C.E, and the patronage of learning by the Persian emperors made some famous neo-Platonist philosopher-mathematicians flee to the Academy of Jundishapur. Thus Jundishapur became an international centre of medical teaching through the hotchpotch of Greek, Hindu, Syrian, Persian and other works on medicine. Sergios of Resaina was one of the greatest translators who translated philosophic, scientific and medical books from Greek into Syriac. Boetius was also a philosopher-mathematician and was popular for carrying Greek thought to the Latin West (Nakosteen 1964). Among the reputable scholars of the period were Varahamihira, Aryabhata and Latadeva. Others included Moschion, a Latin gynecologist, Alexander of Tralles, a Byzantine physician and Philoponos of Alexandria who was regarded as the greatest physicist of his age (Husaini 1986). Such was the situation in Arabia and its contemporary civilizations at the dawn of Islam.

The expansion of Islam coupled with the contact of the Muslims with these cultures undoubtedly influenced their thought. They therefore commenced the translation of these foreign works into Arabic first at individual level, and this later became a matter of public concern during the Abbasid caliphate particularly during the tenure of Al-Ma'mun (813-833C.E). Scientists and translators like Hunayn ibn Ishaq, Masarjawayh, Thabit ibn Qarrah and Isa ibn Yahaya were notable scholars who translated several books into Arabic. This effort made Baghdad the greatest centre of learning at that period. The Muslims did not stop at translating foreign works into Arabic; they made independent observations and contributions to different branches of science; embracing those that were compatible with their religious doctrines and modifying others to suit their purposes. Their active involvement in the study of these foreign sciences was fruitful as they later became authority in them and consequently transmitted them to another generation of both Muslims and non-Muslims.

At this juncture, it is necessary to identify the nature of the contributions of the Muslims to sciences. In the field of Chemistry, such substances and compounds as carbonate of soda, alum, borax, bichloride of mercury, nitrate of silver, sulphuric acid, hydrochloric acid, potassium hydroxide, potassium nitrate, alcohol and alkali were discovered by Muslim scientists. The chemical process of distillation, filtration, calcinations, sublimation and evaporation were said to have been detected by Jabir ibn Hayyan (Haque 2010). Ibn Al-Haitham's Kitab al-Manazir is considered a masterpiece in the field of optics. He was also said to have constructed a spherical and parabolic mirror and also gave the accounts of atmospheric refraction from concave surfaces (Jumba 1998); while he also gave accurate description of the various parts of the eye and as well explained scientifically the process of vision. Furthermore, al-Khawarizmi (d.226/840) would not be forgotten in the field of arithmetic. He was said to have developed in detail among others trigonometric tables containing the sine functions, as well as astronomical tables in the science of astronomy. Most of the works of these Muslim scientists were translated into Latin and other languages and remained viable references for many scholars in their respective areas of specialization. 
The Muslims' geometric contributions to the sciences later suffered a setback due to internal turmoil, disunity and later colonization by the Europeans who seized the opportunity to translate the Muslims' scientific discoveries into their own language and consequently destroyed the original sources of their works. They therefore de-Islamized the sciences before presenting them to the rest world, thereby gave the false impression that they were the harbingers of sciences. Following the era of decline, the Muslims later realized that their backwardness in all spheres of life was due to the levity with which they handled science; hence the clamour for the Muslims to change their attitude towards acquisition of sciences. Scholars therefore attempted to look at scientific issues from a pure religious perspective. The assertion of Allah that nothing has been left unmentioned in the Quran made Muslims to derive systems and sub-systems of knowledge and culture from the Quran. Some $19^{\text {th }}$ and $20^{\text {th }}$ century scholars therefore carried out modern scientific exegesis of the Quran. Among them were Sir Sayyid Ahmad Khan's six - volume exegesis of the first seventeen chapters (Surat al-Fatihah to Surat alIsra) in 1880, and an Egyptian physician, Muhammed ibn al-Iskandari whose work Kashf alasrar al-nuraniyy al-Quraniyyah (The Unveiling of the illuminating Secrets of the Quran) was described as the first interpretation of the Quran that treats non-Arab occidental sciences (Wan Daud, 1989). Others include Shaykh Muhammad Abduh (d. 1908) and Muhammed Farid Wajdi (d. 1940). Some other professors identified by Zaghloul (1986) to have written the sciences from a true believing perspective are Ibrahim Farag, Muhammad Ahmad El-Ghamrawi, Muhammad Mahmound Ibrahim, Khattab Muhammad, Malek ibn Nabi, Waheed-uddin Khan, Muhammad Said Kira, Mustafa Muhammad, Maurice Bucaille and many others. The Quran thus becomes a source of inspiration to Muslim scientists.

The agitation of the Muslims to review their attitude to education and to reform their education system culminated in the 1977 World Conference on Islamic Education where the concept of Islamization of knowledge became a popular slogan. At the conference, the aims and objectives of education were spelt out, and this consequently led to the emergence of many Islamic institutions, bodies, international universities, and adjustment in the educational curriculum of some Muslim nations. Right from the First World Conference on Muslim Education, science and technology has received good attention in the scheme of the Islamization of knowledge programme. This is probably due to necessity for the reassessment of the contemporary science and technology as well as charting out a new course for the development of a futuristic science and technology from Islamic perspectives. In 1984, the International Institute of Islamic Thought (IIIT) in cooperation with the Government of Malaysia organized an international conference on Islamic thought where the need to promote and undertake the preparation of anthologies on Islamic philosophy of science, Islamic sociology of science and technology, Islamic ethics and values in science and technology was stressed. The various moves to promote and professionalise the Islamic science and technology made some scholars to come together to establish the International Institute of Islamic Science and Technology (IIIST) in 1987 in Washington D.C. The organization was later registered as a non- profit corporation in February 1988 with Prof. Seyyed Hossein Nasir of George Washington University as the chairman Board of Trustees and Dr. S. Waqar Ahmed Husaini as Director General of the Institute. It suffices to state the objectives of the Institute because of their relevance to our discussion. Some of the objectives of the institute are to undertake, promote and encourage:

- the understanding of the teachings of the Quran and Sunnah concerning the world of nature through the use of ijtihad and ijma and an analysis of the Islamic intellectual tradition concerning the understanding of these teachings;

- the development of the Islamic philosophy of science and technology, that is, science and technology as informed by the Islamic world- view, particularly the Islamic philosophical sciences such as metaphysics, logic and epistemology as well as ethics and law, and aesthetics; 
- the development of Islamic sociology of science and technology; that is, to investigate in particular the causes, consequences and prerequisites of the qualitative and quantitative growth, development, decline, and impact of science and technology in Muslim and non-Muslim socio cultural systems, and to determine, in relation to the historical and modern Muslim cultures, the Islamic paradigms of the birth, growth, world supremacy, decline, and contemporary rebirth of Islamic science and technology;

- the development of the Islamic history of science and technology; that is, the evaluative and descriptive study of the history of non-Muslim and Muslim, preQuranic and post-Quranic, science and technology from the Islamic point of view as well as the study of such cognate disciplines as magic, superstition, and the esoteric sciences; and in particular, the thorough study of the history of Islamic science and technology from the earliest to contemporary time using their primary sources.

Furthermore, one of the oldest professional organizations under the auspices of the Muslim Students Association is the Association of Muslim Scientists and Engineers which was organized in North America in 1969 C.E/1389A .H. The aims and objectives of the association are:

- to coordinate the activities of Muslim scientists and engineers in North America;

- to pursue a course toward creating awareness that scientific research based on Islamic principles is needed to provide the ummah with viable alternatives to secular western technology;

- to identify Muslim scientists and engineers and mobilize them through seminars, conferences and group discussions to make them aware of the relevance of Islam to their disciplines.

The association has taken the bull by the horns by organizing programmes for its members to contribute and contemplate on the challenges facing their areas of specialization. These are done through discussions, presentations and publication of researches for the purpose of enhancing professional development and Islamic understanding. Its annual conferences attract Muslim professionals from North America and overseas. The association also publishes a journal - The Muslim Scientist. The workshop on 'Islamization of Attitude and Practice in Science and Technology' which was held in Washington, D.C, in 1987 was organized by this association in collaboration with the IIIT. The workshop was organized with a view to discussing the 'problems and challenges of science with respect to the ideology, personality, education and environment of a Muslim scientist in the contemporary world, in relation to the past and the future.'

From the above, one feels comfortable to identify five stages of development of science amongst the Muslims as against four identified by Galal (1978) and Sokoto (1998).The first stage is the stage of translation cum formation (750-900C.E) when such Abbasid caliphs as Al-Mansur, Harun Rashid, al-Ma'mun and Al-Mutawakkil encouraged the work of translation on a scale unequalled by establishing the Baytul-Hikmah (The House of Wisdom). The second stage is characterized by the Muslims' strong contribution to sciences through their independent observations and discoveries. During this period, many Muslim scientists and philosophers emerged making their breakthroughs in their respective fields. This is the stage Galal (1978) refers to as the stage of efflorescence. The third stage marked the spread of the Muslim sciences to other political centres through sponsorship of scholars and technicians by Muslim rulers and some rich merchants. This is described by Sokoto (1998) as the period of the rise of the 'European Surgery in Western Asia' when Islamic sciences were transmitted to the West through the translation of Arabic works into European languages. The fourth stage is the stage of decline when the Muslims stopped scientific researches and discoveries and so resorted to taqlid due to 
internal problems and colonization of the Muslim land. The fifth stage is the stage of agitation and advocacy for Muslims to re-embrace science and integrate it into the mainstream of religious education. This is the stage of re-Islamization of the sciences. However, it is our candid opinion that Muslims should move to another stage, this time, to strategize how the Ummah could forge ahead to regain their past glory in the sciences, not through painting already discovered scientific facts and theories with Islamic coloration, but coming up with new discoveries like their predecessors had done in the past. Lamenting on the precarious status of science in the Muslim world today, Ahmed (2005) writes:

One wonders about the possible shape of the world today if Muslim scientists had been able to continue their research and scholarly work. Today, Muslims are seriously underrepresented in science. Less than one percent of the world's scientists are Muslim, whereas 25 percent of the world's population are Muslim. Muslims have developed a false perception that all knowledge is in the Quran. Most conservative Muslims discourage the study of science, regarding it as 'Western'.

\section{Why Must Science and Religion Go Together?}

From all indications, science and religion are meant for human development; hence the two are expected to be blended together for fruitful result. Science is highly significant in the life of human beings. With it, communication, transportation, space exploration and others have been made possible. In the area of medicine, drugs and vaccines have been made available to save mankind from different ailments and deadly diseases. Science has also gone extra mile to replace defective body organs with either artificial ones, that of animals or rather from ones donated by others. There have been instances of kidney, limbs and hearts transplanting. This development to us showcases the vicegerency of human kind on earth.

In addition, religion particularly Islam could also substantiate its stands through the use of science. For instance, it can be used to determine the compatibility of spouses before marriage, determining the paternity of a child, calculating the fractions allotted to heirs, and a host of others. The implication of this is that scientific endeavours are meant to fulfil divine injunctions. A clear indication of this submission could be inferred from Al-Khawarizmi AlFarghani who went into Algebra for the purpose of solving problems of inheritance and commerce as taught in the Quran (al-Faruq 2003). This indicates that science and religion are sources of civilization and are meant to develop mankind. An attestation to this could be inferred from the writing of Taeb and Kambu (2008) thus:

Science and religion are part of what made civilizations to evolve. Success or failure of civilization is influenced by the extend (sic) societies are equipped with what they need to help their survival and their development, religion and science being two of the most important such factors ... Religion and science cannot remain indifferent to the forces driving the needs for development.

The fact that the Quran makes references to some scientific facts attests to the relationship between religion and science. The first revelation to the Prophet attests to the close relationship between these two entities. Muslims are therefore enjoined in various verses of the Quran to study the nature of the earth and heavens (Q. 3: 190-191), and as well mentions some scientific facts related to such disciplines as Biology (Q21:30; 6:99; 22:5 etc), Physiology (Q23:12-14); surgery (Q. 94:1); Physics (Q24:35); Chemistry (Q57:25) and Geology (Q79: 32; 27:61 etc) to cite but a few. These and many other scientific verses in the Quran might be what amazed Bucaille (1993) to have concluded that the Quran contains 'many observations on natural phenomena and includes explanatory details which are seen to be in total agreement with modern scientific data'. This is also true of many Prophetic sayings. A good example of this 
is a hadith which gives an account of stages of fetus in the womb of pregnant women. The precision of that account in that period when sophisticated hi-tech medical and scientific equipment like telescopes, microscopes, ultra-sound or scanning machine had not been invented confirms the prophethood of Muhammad. Furthermore, it has been observed that the responsibility of man as a vicegerent of Allah on earth could hardly be achieved without resorting to the sciences. Imaduddin Khalil (1991) opines that the principle of khilafah put forward in the Quran and Sunnah could be upheld and realized through science. He submits further:

Muslims cannot carry out their functions as vicegerents, or obtain sufficient guarantees and assistance to enable them to achieve their objectives of perpetual progress unless they use scientific research methods and methodologies to discover the laws of the world, nature, and the cosmic system. Only then can they 'plug in' to their reserves of energy and achieve a greater harmony between themselves and their environment. Without this, the principle of khilafah is no more than a theory or a dogma in a vacuum.

Khalil (1991) further identifies other Islamic principles which could not be achieved without science. These are:

- The Principle of Tawazun: This is the balance between one's spiritual and material needs. - The Principle of Taskhir: This implies that the world and nature have been made subservient to humanity and so must be explored judiciously for its development.

- The Principle of necessary link between creation and the Creator. Here scientific discoveries, proofs and mathematical calculations have assisted in revealing that the cosmos must have originated from a supernatural and all-powerful Being - Allah.

The above indicates the close relationship between science and religion. It therefore implies that since science has to do with the study of nature and the universe, it should be in consonance with religion, which is revealed by God, the Creator of nature and the universe. A complete human society could therefore be enhanced in an atmosphere where religion and science are made to complement each other. This assertion is better captured by Dauda (1999) when he writes:

\footnotetext{
Man as God's creation studies other parts of God's creation and appropriates them for his use. Man cannot survive independently of other God's creation. From the earth he eats, just like plants and animals which also live on the earth. The knowledge or the intellect given to man is to enable him to use part of this God's creation for his benefits, such that he can be able to live a normal life to worship God, to obey His commandments and to give thanks to Him. Since science is borne out of knowledge given to man by God, therefore science and Islam are not independent. Both go together and are inseparable. It can be said that science is part of Islam because science is the study of God's creation and Islam is the worship of God and obedience to His commandments.
}

In other words, where science is allowed to elbow out religion in its scheme, morality will be downplayed, rancor will ensue and fasad will become rampant. As such, scientific discoveries which are meant to positively impact human existence will adversely be used to threaten it. An outcome of any scientific discovery devoid of religion results to all sorts of social degeneration such as abuse of drugs, murder and crime, suicide, euthanasia, indiscriminate acquisition of nuclear and other weapons and legitimization of such unnatural acts like sodomy, homosexuality and sadomasochism. Wars, genocide, persecution and torture therefore become the order of the day because God has been banished from the scheme of the sciences (Sarwar 1996). It has to be mentioned here that some scholars like Wajdi (cited by Abdul Rahim 2011) believe that science aids the interpretation and comprehension of the physical world and 
development of resources, while religion provides the spiritual and moral dimensions of civilization. While this fact can be true to a large extent, we strongly believe that religion particularly Islam should also share the attributes of the sciences in interpreting and comprehending the physical world and development of resources. This is due to the fact that the Quran has been severally referred to as a veritable source of scientific discoveries from where scientific facts can be expounded.

\title{
The Imperative for Islamicizing the Sciences
}

The dichotomization of knowledge into dini and duniyawi has been extensively criticized by many scholars. While Al-Faruqi (1982) sees this division as the root cause of Muslim backwardness, Mawdudi sees it as a clever way of reducing Islam to mere creed and ethics whereas it encompasses the entire gamut of human life. As such, sciences such as medicine, engineering, mathematics, psychology, sociology and others must be seen within the purview of Islam. Apart from the above, science could not be considered as being value-free and independent of a particular worldview because scientists are also influenced of one value or the other. This explains why Golshani (2000) objects to the proposal that there could be religious scientists but not religious science because there could be only one kind of science. Reacting to this, he writes:

\begin{abstract}
If scientific books were reflecting purely scientific findings, not being colored by metaphysical commitments and inclinations of scientists, we could in some sense consider science free from worldviews, and attribute the words 'religious' or 'secular' to scientists rather than sciences. But practically, this is not the case, and the presentation of scientific findings is always accompanied by a sophisticated web of judgments including the religious or philosophical prejudices of the scientist involved.
\end{abstract}

However, as useful as science is, scientists at times delve into what is neither relevant to them nor to the human race. Out of pomposity, scientists have gone to the extent of sex change, genetically enhanced physical and mental characteristics of unborn child through cloning, and embarking on such processes of procreation through In-Vitro fertilization (IVF), the first which took place in 1978 in Britain. Others include Artificial Insemination (AI), Garmate Intra Fallopian Transfer (GIFT), Intra Cytoplasmic Sperm Injection (ICSI) and ZygoteIntra Fallopian Transfer (ZIFT) all which are embarked upon not minding their legal and spiritual implications (Balogun 2007). This therefore implies that not all scientific findings serve positive purposes, hence the need for religion to check the excesses of science. In addition to this, it will be disastrous for the Muslims to keep quiet watching the invention of massive destruction weapons and other high explosives used in the aerial and land bombings by the so-called world powers because the effects of this development will not only bounce on their inventors but also on innocent citizens. It cannot be doubted that the climate change being witnessed today is a resultant effect of all these atrocities, hence the need for religion to come to rescue.

Apart from the above, many verses of the Quran call on man to ponder and investigate into natural endowments with a view to realizing the uniqueness of Allah, as well as researching into them for his benefits. The earth, the sky, the star, the sun, the moon, the clouds, the rain, the movement of the wind, the sailing of the ships through the ocean, the plants, the animals including man himself are mentioned in the Quran as sources of knowledge to man. Scholars consider the study of these natural phenomena a religious duty, hence Islamicizing the sciences becomes imperative. This is confirmed by Siddiqui as cited by Deedat (n.d.) when he says:

The stress, which the Holy Quran has laid on the scientific study of the universe, is a phenomenon unique in the religious literature of the world. Repeatedly it exhorts the 
Muslims that the pursuit of scientific knowledge is one of their religious duties . . that everything in nature is for the service of man and should be harnessed by him for his use.

Finally, some modern inventions could serve as evidence to prove some eschatological matters in the Quran. For instance, the invention of video machine could be used to confirm that Allah takes record of all human actions on earth and such will be relayed to them on the Day of Accountability. In the same vein, that the records of all human actions are tied to their neck could be confirmed through the invention of flash drive and CDs which can store thousands of volumes of books.

\section{Islamicizing the Sciences: Can It Take Us to the Promised Land?}

The assumption that the sciences need little or no iota of Islamicization may be true to some extent, but one cannot doubt the fact that the aims and objectives of embarking on a scientific research coupled with the methodological approach to such a research may demand Islamicization for such to be useful for human consumption and as well attract celestial reward. It is therefore not an effort in futility for the scholars who stress the need for Islamicization of the sciences. However, approaches to Islamicizing the sciences demand to be critically studied for one to determine the end-result of the efforts. To start with, Syed Ahmad Khan (1817-1898) attempted to make Muslim theology compatible with post-Renaissance Western humanistic and scientific ideas with the belief that this was the only way the Muslim could move forward. He therefore frowned at the attitudes of some religious figures who were anti-science. He strongly believed in the infallibility of science, hence proposed that the Quran be reinterpreted so as to remove all apparent contradictions with physical reality. Khan proposed that some historical happenings, which contradicted scientific truth like the miracles of Jesus, the Isra'I wal- Micraj episode and the like in the Quran, be given metaphorical interpretation. This approach of Khan had been seriously criticized by other reformers and scholars. To Jama-ad-Din Afghani, this strategy amounts to Westernization of Islam and a deliberate attempt to sell out the Muslim world to the West for his selfish end. In his own view, al-Faruqi (1988) stresses the devastating cumulative effects of Khan's approach on the Muslim world, seeing it as imposition and an attempt to de-Islamize the top layer of Muslim society and demoralizing the rest. This approach could therefore be seen as inimical to the taste of the Muslims, as it is counter-productive.

Another approach adopted by the Muslims is what can be referred to as Bucaillistic Approach. This is an approach otherwise called Relational Approach which reduces the Quran to mere confirmation of scientific proofs and makes Islam relevant to science and technology instead of making science relevant to Islam. This approach was adopted by Maurice Bucaille where he tries to juxtapose Quranic scientific verses with some scientific findings trying to use Quranic verses to buttress a scientific theory. The danger of instability in scientific theories and frequent revision has been seen as a shortcoming in the sciences which can adversely affect the Quranic verse used to confirm such theory if eventually becomes obsolete. According to Ibrahim (1990), 'The Quran is the domain of eternal absolute truth; science's domain is relative truth and changing facts'. As such, it will be dangerous to justify and compare what is absolute truth with what is relative, as one will be tempted to modify the absolute when the relative changes. Quraishi and Ali-Shah (1989) gives examples of such scientific theories like the atom which was once considered indivisible but later stood as badly shattered as the atom itself; the concept of conservation of mass which was once a fundamental 'law'; but not even a theory now. Others include the importance of fats to human health, which was later proved harmful due to effects of cholesterol accumulation. Thus, it is not enough to use verses of the Quran to support some scientific discoveries; rather, scholars are expected to discover important scientific facts and create new concepts just as Al-Jazari and Omar Khayyam discovered intricate machines and solution of cubic equations respectively. For instance, the Quran is 
evidently the source of inspiration to Ibn Firnas, an Arab scientist who attempted to find a way of flying in the space.

Adebayo (2011) further identifies and criticizes some approaches adopted by the Muslims to integrate sciences into Islam. These include:

- The Source Approach: This is a method of making references to the Quran during the course of teaching science and technology and other social science concepts.

- The Relational Approach: This is a method of relating scientific and technological concepts and principles to the Quran and sunnah in form of either expounding scientific facts from the Quran and Hadith, and searching for scientific proof of the Quran.

- Tributary Approach: Here, attempts are made to amplify the contributions of the Muslims in the advancement of science and promotion of intellectual activities. Scholars who had made landmark history in the sciences are eulogized for their contributions in their respective scientific breakthroughs.

Apart from the above, some scholars have equally attempted to rewrite science from pure Islamic perspective in their own initiative. Zaghlul (1988) for instance, gives a 16-step strategy for achieving this goal. All the 16 steps are geared towards integrating science and Islam and not to discover new sciences based on the Quran and hadith. In the same vein, Ragab (2009) in his The Methodology of Islamizing Human Sciences, came up with a two phase strategy, namely integral theorizing and validation through research and practice. The first phase has the following steps: Critical Review of Relevant Human Science Literature; Critical Review of Relevant Islamic Material; and Development of the Unified 'Integral' Theoretical Framework, which is where the sifted-out insights generated from both Islamic revealed knowledge sources and 'valid' human experience are combined through cataloguing and organizing, rearrangement and reinterpretation and finally statement of the results. The second phase, to him becomes necessary in view of the fact that the process of integration is a human effort and that formulations cannot be seen to be true a priori, and so, it becomes imperative that the formulations are subjected to rigorous tests in reality to check on their truth-value-in conformity with the time-honoured ethos of science. This can be done through hypothesis testing and validation. A confirmation of such hypotheses increases the confidence in that framework and if unconfirmed, it implies incorrect interpretation of revelation included in the integral theoretical framework or that the research procedures were faulty. Under normal situation, it is not expected that there is any contradiction between the correct interpretation of the revelation (valid scripture) and corroborated facts. That not-withstanding, each of the above approaches is with its shortcomings which do not make it a true representative of what actually should be the contributions of Muslims to sciences as it was before, hence the need to take a step forward. The imperative for this is stressed by Ibrahim (1990) when he submits:

Recent research has highlighted these and other achievements of Islamic science. But despite all this, there is still much to be discovered. We have not delved deeper into the substance and real essence of the scholarship, other than making some descriptive historical accounts of the works and their authors. In retrospect, we now realize, for example, that the Islamic science community has not yet produced its own Joseph Needham, whose epochal achievements in undertaking the study of the history of Chinese science has now become public knowledge. But we knew from existing documentation and studies that the history of Islamic scholarship has bequeathed a large enough amount of material for present-day Muslim scholars and scientists to unveil the underlying structure and spirit of medieval Muslim scholarship. 
In view of the above, Ibrahim (1990) calls on Muslims 'to look at Islamic science in history in terms of its systematic structure, the conceptual processes that were at work, and the research modalities upon which the Muslim scientists undertook their research'. To buttress this, he came up with a quotation from an Algerian thinker, Malek Ben Nabi who says: "A society which does not have its own guiding ideas can make neither its consumer goods nor its equipment. It is not by means of ideas imported or imposed that a society can develop. We must recover our intellectual originality before we can regain our political and economic independence".

\section{Moving a Step Further}

From all indications, Islamicizing the sciences has made the ummah to appreciate the landmark achievements of Muslim scientists as well as the relevance of the Quran to modern sciences and discoveries. These however may not take the Muslims anywhere if they continue to eulogize their past heroes without making their own contributions to the sciences. They therefore need to find out how the past Muslim scientists were able to make their own impacts felt in the world of sciences rather than relying solely on the discoveries of civilizations before them. Muslim scientists of the previous centuries would not have made any useful contribution if they had made reference to some Quranic verses to buttress a scientific discovery without making their own discoveries. It is in this wise that it becomes pertinent to set mercenaries in motion for their own scientific breakthroughs.

In the first instance, the backwardness of the Muslim world has been attributed to the levity with which it handles science and technology. As such, right from the primary ladder of education, Muslim children should be exposed to elementary science in addition to their learning the Quran and Arabic language. This will assist them to appreciate the science as an inevitable subject for them to learn. Muslim primary schools must therefore adopt a 'catch them young' science programme by exposing the primary school pupils to science and making its teaching interesting and practical by the introduction of the 'do it yourself' package to them. For instance, the pupils should not only be taught the topic: 'Measurement', but must be shown such measuring instrument as thermometers for measuring temperature, rainguage for measuring rainfall, wind vane for determining the direction of the wind, anemometer for measuring the speed of the wind and light meter for measuring light intensity. Teaching measurements in abstract may not make the topic interesting, and showing them the instruments of measurements may not achieve the desired results if the pupils are not allowed to put them into use themselves. In other words, involving them directly with the aims, procedures, observations and conclusion of basic experiments will help in arousing the interest of the pupils in science subjects. While the pupils are being taught this, they are made to know that what they are measuring like temperature, rainfall, light and wind are created by Allah.

At the secondary level of education, students should be exposed to more practical aspects of science. In other words, more periods must be spent in the laboratory than on theory. At this level, the idea of excluding science students from taking Islamic Studies and Arabic language as it operates in some countries like Nigeria should discontinue, as this creates a serious bifurcation between science and religion. Also, science at the primary and secondary levels of education will be made more interesting and fascinating if it is taught in the native language of the students, though some scientific terms may be difficult to render in local languages.

At the tertiary level of education, independent research and experiments should be encouraged among the students. Rather than teaching them how to measure temperature for instance, they should be encouraged to devise their own instrument of measurement. With this, reliance on a single method of measurement will be discouraged and new instrument will be devised. In order to ignite stimulus to scientific research among the Muslims, Muslim universities must rise to the task of producing thoughtful and industrious creative men of 
thinking by employing the faculties of thinking and searching and probing into the mysteries of the universe and uncovering the treasure of powers hidden in the nature.

To achieve the above, it is our candid suggestion that Muslim scientists in various fields must rise to the task of publishing simple science books at elementary and secondary levels of education taking into consideration the major needs of the Muslim world in the field of science. In addition, various governments of different Muslim states must embark on rigorous training of secondary school teachers even if that will involve recruiting experts who are non-Muslims, after-all, knowledge is a stray camel of the Muslims which should be taken wherever it is found. Muslim school laboratories must be equipped with necessary equipments and materials that will aid students' learning. Also competitions among Muslim schools should be encouraged in science and technology through students' science based clubs and organizations at secondary school levels where students will display their inventions and outcome of their experiment.

At tertiary education level, one needs to stress the need for the Ummah to focus their attention on establishment of international universities of science and technology for the purpose of focusing extensively on scientific and technological discoveries. The establishment of King Abdullah University of Science and Technology in Thuwal, Saudi Arabia and that of Islamic Science University among others are a right step in the right direction for this purpose. Universities of this nature should also collaborate with other renowned universities in other nations and continents to pool resources for creative application of sciences and technology for human development and for promoting the transfer and exchange of scientific knowledge and experience. Symposia, conferences and workshops should also be organized to showcase their scientific breakthroughs for the purpose of publicity.

As a conclusion, so far attempts had been made to trace the close relationship that was supposed to be between religion and science and how the theologians before Islam selfishly disallowed that and destroyed the unity of knowledge by persecuting and executing the scientists, believing that they were out to bring the Church into disrepute. The active roles played by the Muslims in all fields of the sciences and the relevance of science to religion had also been explored. In the same vein, we have also delved into various steps and strategies taken by scholars to bring the sciences into normal Islamic axis by Islamicizing it.

We want to quickly add here that these measures at bridging the gap between the science and religion have seriously been criticized by some scholars who believe that it is an effort in futility to have what can be called 'Islamic science' derivable from pure Islamic origin. While we admit the unity of knowledge and the fact that all knowledge emanate from a single source - Allah, it cannot be denied that knowledge at time is value-laden being influenced by the environment, the carrier, the transmitter and the methodology used. As such, Islamization of the sciences should be seen as a means of ensuring the unity of knowledge with a view to universalizing it. We therefore concour with the view of a seasoned Professor of Medicine, Omar Hasan Kasule (2001), who submits that successful discipline reform must be characterized by pro-active intellectual effort, academically and methodologically rigorous, objective and have practical consequences and such a reform should be of paradigms, methodology and uses of knowledge and not its contents. That the contents may not be Islamized might be an oversight on the part of the Professor, as at times, the contents too may need some Islamization touch. That notwithstanding, the type of Islamic science we have in mind is that which immortalized the achievements of scientists in Islam's Golden age. As such, Muslims in the field of sciences should rise to the task of making researches on aspects of their disciplines with a view to making breakthrough discoveries like Ibn Sina's monumental achievements in medicine; AlIdrisi in making the first map of the world similar to those made by modern cartologists; Ibn AlHaitam being the first to draw the eye and Jabir ibn Hayyan as one of the first modern chemists for his discoveries of acids. When Muslims do this, they would certainly be contributing immensely to the field of science and unless this is done, the Muslim world will continue not 
only to be a mere imitator of western legacy and values, but also an Ummah of consumption and importation of Western discoveries.

\section{References}

Abdul Rahim, Adibah. 2011. Muhammad Farid Wajid's discourse on the integration of religion and science. In, Ushama Thameem (ed.). Islamic revealed knowledge dimensions of thought. Kuala Lumpur: IIUM Press.

Adamu, U.F. 2002. Medicine in the Quran and Sunnah. Kano: IIIT Nigeria Office.

Adebayo, R.I. 2008. Islamization of knowledge: Global developments, individual efforts \& institutional contributions. Kano: IIIT Nigeria Office.

Ahmed, M. Basheer. 2005. Contributions of Muslim physicians and other scholars. In Ahmed, M. Basheer, Ahsani, Syed A. \& Siddiqui, Dilnawaz A. (eds.). Muslim contributions to world civilization. Herndon: International Institute of Islamic Thought \& Assocation of Muslim Social Scientists.

Balogun, K.A. 2007. Revisioning modernity in the eyes of religion. In, Folorunsho, M.A; Oyeneye, I.O \& Adebayo, R.I. (eds). Religion and modernity. National Association for the Study of Religions and Education (NASRED).

Bucaille Maurice. 1993. The Bible, the Quran and science: The Holy Scriptures examined in the light of modern knowledge. New York: St. Martin's Press Publisher.

Dauda, Y. 1999. Islam, Science and survival of mankind. Lagos: Iman Services Ltd Publishers.

Deedat, A. n.d. Al-Quran the miracle of miracles. Lagos: Al-Balgh Publishers.

De Lacy O'Leary. 2002. How Greek Science passed to the Arabs. New Delhi: Goodword Books Pvt. Ltd.

al-Faruq, Abu Umar. 2003. Islamaphobia: The Story of fear and hate by the West. Lagos: Salsabil Associates.

al-Faruqi, Isma il R. 1988. Islamization of knowledge: problems, principles and prospective. In Islam: Source and purpose of knowledge. Herndon: IIIT.

Galal, A. 1978. Islam and Science. Cairo: Dar al-Mokhtar al-Islami.

Golshani, M. 2000. How to make sense of Islamic science. The American Journal of Islamic Social Sciences 17(3).

Hamidullah, M. 1981. Introduction to Islam. Lagos: Islamic Publications Bureau.

Haque, M. 2010. Contribution of Muslim scholars to the sciences. In Haque, M. et al. (eds). Islam, knowledge and civilization. Kuala Lumpur: IIUM Press.

Hoodbhoy, P. 1991. Islam and science: Religious orthodoxy and the battle for rationality, London: Zed Books Ltd.

Husaini, S.W.A. 1986. Islamic Science and public policies: Lessons from History of Science. Malaysia: n.p.

Ibrahim, A. 1990. Towards a contemporary philosophy of Islamic science. The American Journal of Islamic Social Sciences 7(1).

Jumba, A.M.Y. 1998. The contributions of Islam to science and technology. In, Sambo, A. S, et. al (eds.). Islam and the development of science and technology. Sokoto: Islamic Research Centre.

Kasule, O.H. 2001. Islamization (reform) of disciplines of knowledge: procedures and processes. A paper presented at the $6^{\text {th }}$ World Conference on Islamic Education, Cape Town, South Africa, on 19 - 25, September, 1996) in IBERR, IBERR's Manual For Muslim Schools; Cape Town.

Kealy, Sean P. 1978. Science and the Bible. Ireland: The Columbia Press.

Khalil, I. 1991. The Quran and modern science: observations on methodology. The American Journal of Islamic Social Sciences 8(1). 
Nakosteen, M. 1964. History of Islamic origin of Western education A.D 800-1350. Colorado: University of Colorado.

Quraishi, M. Mahmud \& Ali Shah S. Maqsud. 1989. The role of Islamic thought in the resolution of the present crisis in science and technology. In Toward Islamization of Disciplines. Virginia: IIIT.

Ragab, Ibrahim A. 2009. The methodology of Islamizing human sciences. In Hussain, Mohd Yusof (ed.). Islamization of Human Sciences. Kuala Lumpur: IIUM Press.

Sarwar, Ghulam. 1996. Islamic education: its meaning, problems and prospects. In Issues in Islamic Education. London: The Muslim Educational Trust.

Sokoto, A.A.S. 1998. Islam and the value of knowledge: a survey of the contribution of ulama in scientific and technological development. In Sambo, A. S et. al (eds). Islam and the development of science and technology. Sokoto: Islamic Research Centre.

Wan Daud, W.M.N. 1989. The Concept of Knowledge in Islam and its Implications for Education in a Developing Country. London: Mansell Publishing Ltd.

Taeb Mohammad and Kambu Alphonse. 2008. Building on synergies between science and religion: A Key element for sustainable development. In Takeshi Kimura (ed.). Religion, Science and Sustainability. Osaka: Union Press.

Zaghloul, R. El-Nejjar. 1986. The Limitations of science and the teachings of science from the Islamic perspective. American Journal Islamic Social Sciences 3(1).

Zaghloul, R. El-Nejjar. 1988. Islamizing the teaching of Science: A Model in challenge and response. In, Islam: Source and Purpose of Knowledge. Herndon: IIIT. 